\title{
Analisis Pengaruh Konflik Keluarga dan Pekerjaan Terhadap Kepuasan Kerja pada Dosen di Perguruan Tinggi Swasta di Kota Prabumulih, Sumatera Selatan
}

\author{
Maiza Fikri \\ AMIK Bina Sriwijaya Palembang \\ Email:maizafikri@rocketmail.com
}

\begin{abstract}
Conflicts of interest between family and work there in general is often experienced due to work properly guided so that job satisfaction can be created with good. Factors that affect the family-work conflict terhadapan satisfaction that type of work, work location, behavioral couples, and salary. The design of this study is descriptive quantitative research with taking three object in Colleges precisely on the other side of Palembang city namely the STMIK YPP Prabumulih, STIE YPP Prabumulih and STIE AL-Furqon. Methods of data collection using questionnaires, the number of respondents is 75 and using incidental sampling technique. This study aims to find out there is a family-work conflicts influence on job satisfaction at the faculty. Didgunakan analysis is simple regression analysis, analysis of correlation coefficients and coefficients of determination. By using simple regression can be concluded that the family-work conflict there is significant influence on job satisfaction with a $\mathrm{P}$ value of $0.000<$ value of 0.05 , whereas the correlation analysis of the results obtained Person bivariate correlation between conflict and satisfaction is -0.421 which means there is no way the relationship between variable work-family conflict and job satisfaction variables, while the value of sig (2-tailed) obtained 0,000, which means a significant $<0.05$ then there were significant correlations (Ha accepted).
\end{abstract}

Keywords: Job satisfaction, work-family conflict.

\section{Abstrak}

Konflik kepentingan antara keluarga dan pekerjaan yang ada pada umumnya sering dialami karena dituntun untuk bekerja secara baik agar kepuasan kerja dapat tercipta dengan baik. Faktor-faktor yang mempengaruhi konflik keluarga-pekerjaan terhadapan kepuasan yaitu jenis pekerjaan, lokasi kerja, prilaku pasangan, dan gaji. Penelitian dengan mengguakan desain Deskriptif Kuantitatif yang mengambil objek pada 3 Perguruan Tinggi Swasta di Kota Prabumulih yaitu pada STMIK YPP Prabumulih, STIE YPP Prabumulih dan STIE AL-Furqon Prabumulih. Metode pengumpulan data menggunakan kuesioner, dengan jumlah responden sebesar 75 orang dan menggunakan teknik sampling incidental. Penelitian ini bertujuan untuk mengetahui terdapat pengaruh konflik keluarga-pekerjaan terhadap kepuasan kerja pada dosen. Analisis yang didgunakan adalah analisis regresi sederhana, analisis koefisien korelasi dan koefisien determinasi. Dengan menggunakan regresi sederhana dapat disimpulkan bahwa konflik keluarga-pekerjaan terdapat pengaruh signifikan terhadap kepuasan kerja dengan nilai $\mathrm{P}$ value $0,000<0,05$, sedangkan dari hasil analisis korelasi bivariate person didapat korelasi antara konflik dan kepuasan adalah -0,421 yang berarti tidak terdapat arah hubungan antara variabel konflik keluarga-pekerjaan dan variabel kepuasan kerja, sedangkan nilai sig (2-tailed) yang didapat 0,000 yang berarti siginifikan $<0,05$ maka ada korelasi signfikan (Ha diterima).

Kata kunci: Kepuasan kerja, konflik keluarga-kerja.

\section{Pendahuluan}

Profesi dosen dalam suatu perguruan tinggi swasta yaitu mendidik profesional dan ilmuwan dengan tugas utama menstransformasikan, mengembangkan, dan menyerbarluaskan ilmu pengetahuan, teknologi, dan seni melalui pendidikan dan penelitian. Profesi dosen merupakan bidang pekerjaan khusus yang dilaksanakan berdasarkan prinsip-prinsip yang sesuai dengan bakat, minat dan memiliki kompetensi yang diperlukan sesuai dengan bidang tugasnya.Pada perguruan tinggi swasta maupun negeri dapat dibagi menjadi dua golongan besar yaitu tenaga pengajar dosen tetap dan 
dosen luar biasa.Yang termasuk kedalam dosen tetap yaitu dosen tetap yayasan dan dosen tetap PNS. Dosen tetap harus memiliki kualifikasi akademik, kompetensi, sertifikat pendidik, sehat jasmani dan rohani, serta memenuhi kualifikasi lain yang di persyaratkan satuan pendidikan tinggi tempat bertugas.

Kedisipinan terkadang menjadi konflik pekerjaan bagi seorang dosen. Dosen yang seharusnya menjadi panutan bagi mahasiswa terkadang juga melanggar waktu kuliah yang di tetapkan. Terdapat berbagai konflik yang dialami oleh dosen yaitu yang berasal dari beban kerja yang berlebihan dan waktu seperti pekerjaan yang harus diselesaikan terburu-buru atau dealine sehingga kondisi tersebut membawa dampak pada saat di kelas. Konflik yang sering dialami dosen selanjutnya yaitu dapat dilihat melalui konflik keluarga-pekerjaan.konflik ini sering terjadi di keluarga-pekerjaan yaitu tekanan sebagai orang tua dan tekanan pernikahan. Di satu sisi lain sebagai seorang dosen di tuntun untuk bekerja sesuai dengan beban kerja yang baik. Jika terdapat masalah dalam keluarga terkadang seorang dosen melalaikan tugasnya sebagai seorang dosen yaitu tidak masuk mengajar atau sekedar memberi tugas saja. Fenomena seperti ini yang sering terjadi jika terdapat masalah dalam keluarga maupun dipekerjaan dapat menimbulkan konflik di dalam kelas seperti marah secara tiba-tiba tanpa sebab yang pasti,jarang masuk mengajar tanpa alasan. Adanya peran ganda pada profesi dosen tentu memunculkan konflik peran dan kelelahan emosional dalam diri seorang dosen yang mempunyai konsekuensi atau dampak terhadap dosen,utamanya pada tingkat kepuasan kerja.

Terdapat pengaruh konflik keluarga-pekerjaan terhadap kepuasa kerja dari seorang dosen. Terutama pada sisi kepuasaan kerja, tuntunan keluarga, kecemasan dan kelelahan yang menunjukkan hasil yang lebih tinggi karena disaat mengalami masalah keluarga seorang dosen kadang tidak masuk untuk mengajar, disitu menjadi kendala atau konflik bagi seorang dosen sehingga membuat kinerja mereka kurang baik. Jika seorang dosen mengalami kelelahan otomatis seorang dosen tidak fokus dalam melakukan pekerjaannya, terkadang kelelahan tersebut terbawak sampai kerumah sehingga menimbulkan konflik keluarga yang baru. Kurangnya keseimbangan antara kerja dan keluarga mempunyai pengaruh yang berarti terhadap ketidak hadiran dalam bekerja atau mengajar.Tanggung jawab pekerjaan dan keluarga dapat mengakibtkan rendahnya job satisfaction dan menurunkan hasil kinerjanya.

Dari beberapa studi mengenai konflik keluarga-pekerjaan terbentuk susunan yang membedakan konflik menjadi dua jenis yang berbeda yaitu pekerjaan yang mengganggu kehidupan keluarga disebut konflik pekerjaan keluarga dan kehidupan keluarga yang menggangu tanggung jawab pekerjaan disebut konflik keluarga-pekerjaan (Frone et al., 1992). Salah satu contoh yang menggangu pekerjaan atau konflik keluarga pekerjaan adalah orang tua yang melewatkan waktu bersama anaknya karena panggilan tugas dilapangan.Sedangkan contoh kehidupan keluarga yang mengganggu pekerjaan atau konflik keluarga-pekerjaan adalah orang tua yang harus absen atau terlambat bekerja karena anaknya sakit.

Beberapa penelitian melaporkan bahwa konflik keluarga - pekerjaan akan mempengaruhi beberapa hal dalam kehidupan keluarga dan pekerjaan. Ada hubungan negative antara konflik keluarga dan pekerjaaan dengan kepuasan kerja ( Prasuraman\& Simmers, 2001 ; Huang et al., 2004). Pekerjaan yang mengalami konflik keluarga - pekerjaan tinggi akan 
mengalami ketidakpuasan terhadap pekerjaan dari pada pekerja yang mengalami konflik pekerjaan - keluarga rendah. Konflik keluarga - pekerjaan adalah konflik yang terjadi karena tekanan peran dari domain keluarga dan pekerjaan tidak dapat terpenuhi secara imbang. Berdasarkan pada latar belakang di atas maka penulis membatasi permasalahan dalam penelitian ini yaitu (1) bagaimana pengaruh konflik keluarga-pekerjaan terhadap kepuasan kerja pada seorang dosen? dan (2) faktor apa saja yang mempengaruhi konflik keluarga-pekerjaan terhadap kepuasan kerja?

\section{Literature Review}

\subsection{Konflik}

Konflik berasal dari kata kerja latijn configere yang berarti saling memukul. Secara sosiologi, konflik diartikan sebagai suatu proses sosial antara dua orang atau lebih (bisa juga kelompok) dimana salah satu pihak berusaha menyingkirkan pihak lain dengan menghancurkannya atau membuatnya tidak berdaya. Menurut Killman dan Thomas, dalam Soeharto,T. (2010), konflik merupakan kondisi terjadinya ketidak cocokan antara nilai atau tujuan-tujuan yang ingin dicapai, baik yang ada dalam diri individu maupun dalam hubungannya dengan orang lain.

Kondisi yang telah dikemukakan tersebut dapat mengganggu bahakan menghambat tercapainya emosi yang mempengaruhiefesiensi dan produktivitas kerja (Wujono, 2004, p.4).Menurut Gibson dalam Soeharto,T. (2010), hubungan selain dapat menciptakan kerjasama, hubungan saling tergantung dapat pula melahirkan konflik. Hal ini terjadi jika masing-masing komponen organisasi memiliki kepentingan atau tujuan sendiri-sendiri dan tidak bekerja sama satu sama lain.

Menurut Dahrendorf, konflik dibedakan menjadi 6 macam yaitu (1) Konflik antara dalam peran sosial (intrapribadi), misalnya antara peran-peran keluarga dan profesi; (2) Konflik antara kelompok-kelompok sosial (antara keluarga atau geng); (3) Konflik kelompok terorganisir dan tidak terorganisir ( polisi melawan massa); (4) Konflik antara satuan nasional (kampaye, perang saudara); (5) Konflik antar agama dan (7) Konflik individu dan kelompok.

\subsection{Tuntutan pekerjaan dan keluarga dalam konflik kerja keluarga}

Boyar et al, dalam Soepatini dan Kussudyarsana (2008), menjelaskan tuntunan (pekerjaan dan keluarga) sebagai berikut "a global perception of the level and intensity of respobility with in the work (or family) domain". Suatu tuntunan muncul dari persepsi individu yang mengalaminya agar mempengaruhi pekerjaan dan keluarga. Lebih jelasnya lagi, dalam suatu organisasi yang sama dengan aturan yang sama dan berlaku untuk semua karyawan, ada yang merasa dirinya mendapat tuntunan terbesar dibandingan karyawan yang lain.

Dari tuntunan tersebut selanjutnya muncul persepsi individu bahwa kepentingan pekerjaan menggangu pekerjaan. Meski demikian, keterkaitan antar tuntunan tersebut dapat meminimalkan oleh nilai yang dianut individu dan peran yang sedang dijalankan. Boyar et al dalam Soepatini dan Kussudyarsana (2008) menjelaskan variabel untuk masing-masing domain (lingkungan). Baik domain pekerjaan maupun keluarga memiliki tiga kategori yaitu (1) Karakteristik pekerjaan; (2) Tekanan dari peranan yang dijalankan dan (3) Dukungan lingkungan sosial (perusahaan dan keluarga). 
Dalam penelitian Tanudjaja (2003, vol.2, no.1) bahwa konflik keluarga-pekerjaan berperan sebagai tuntunan kerja karena di dalamnya terdapat konflik interperan dimana tuntunan pada satu peran itu mempengaruhi atau dipengaruhi oleh usaha individu dalam memenuhi tuntunan peran lain, yang merupakan lingkungan keluarga atau pekerja sehingga menjadi stress bagi objek. Sedangkan penelitian menurut Jati (2012) yaitu konflik yang terjadi dari domain pekerjaan berpengaruh pada kepuasan kerja. Pengaruh ini ternyata akan semakin menguat apabila seorang karyawan ternyata mengalami konflik di rumah tangga mereka. Konflik di rumah akan semakin memperburuk konflik di tempat kerja sehingga akan menjadikan kepuasan kerja menjari merosot.

\subsection{Tekanan Pekerjaan}

Tekanan pekerjaan merupakan suatu respon adaptif pada suatu situasi ekternal yang menghasilkan penyimpangan-penyimpangan fisik, psikologi, dan prilaku bagi partisipab organisasi (Luthan dalam Onsardi, 2002). Tekanan pekerjaan juga dapat merupakan suatun kondisi dinamik dimana seseorang individu merasa di konfrontasikan dengan sebuah peluang, kendala dan tuntunan yang dikaitkan dengan apa yang sangat diinginkan dan hasilnya dipersepsikan sebagai suatu yang tidak pasti dan penting (Schuler dalam Onsardi, 2002). Tekanan pekerjaan dapat muncul dari interaksi individu tersebut yang mendorong dari fungsi normalnya (Beerhr \& Newman dalam Onsardi, 2002).

Tekanan pekerjaan ini pula dapat berupa pekerjaan terlalu berat, tidak adanya peran yang jelas dalam pekerjaan, kurang otonomi dan bahkan wewenangnya sering dicampuri oleh atasannya (Frone, Russell \& Cooper dalam Onsardi, 2002). Menurut (Frone, Russell \& Cooper dalam Onsardi, 2002) bahwa beban pekerjaan yang terlalu berat ini dapat dilihat melalui pekerjaan yang dihadapi dan harus dikerjakan oleh pekerja sehari-hari, yaitu (1) Pekerja terlalu banyak pekerjaan yang dilakukan; (2) Merasa memilki tanggung jawab kerja yang lain; (3) Merasa kerja terlalu keras baik secara fisik maupun mental; (4) Merasa tertekan untuk mengikuti cara-cara baru dalam pekerjaan; (5) Mempunyai tanggung jawab yang penting sehingga bila keputusan yang diambil ternyata salah sehingga membuat kerugian yang besar bagi organisasi; dan (6) Pekerjaan yang membutuhkan waktu lama dalam penyelesainya.

Tidak jelasnya peran dalam pekerjaan terlihat dari pekerja yang bingung dan kurang yakin, yaitu mengenai apa yang harus dilakukan, kurang jelasnya tugas yang harus dilakukan, tidak terdapatnya kejelasan tujuan yang harus dicapai, dan bekerja merasa kurang yakin seberapa besar wewenang yang di milikinya. Kurang otonomi atau wewenang ini terlihat dari situasi dimana pekerja tidak mempunyai kesempatan untuk mempengaruhi keputusan atau kurang dapat kebebasan untuk memutuskan diri dalam melakukan pekerjaan yang ada di unitnya, kurang dapat menggunakan inisiatif sendiri dalam melakukan sesuatu dan bahkan terlalu ketat dalam melakukan pengawasan (Frone, Russell \& Cooper dalam Darmayanti Ratna, 2012).

\subsection{Kepuasan Kerja}

Wexley dan Yuki terjemahan Wibowo (2007) mendefinisikan kepuasan kerja adalah cara pekerja merasakan mengenai pekerjaannya. Kepuasan kerja dipengaruhi oleh beberapa aspek pekerjaan, meliputi : (1) upah/gaji, (2) kondisi kerja, (3) pengawasan, (4) teman 
kerja, (5) materi pekerjaan, (6) jaminan kerja, (7) kesempatan untuk maju. Anoraga (2006) mengungkapkan "Bahwa kepuasan kerja merupakan suatu sikap yang positif yang menyangkut penyesuaian diri yang sehat dari para karyawan terhadap kondisi dan situasi kerja, termasuk didalamnya masalah upah, kondisi sosial, kondisi fisik dan kondisi psikologi". Kritner dan Kinicki terjemahan Sutrisno Eddy (2009) mendefisikan kepuasan kerja adalah suatu efektivitas atau respon emosional terhadap berbagai aspek pekerjaan.

\subsection{Konflik Keluarga-Pekerjaan}

Menurut Grenhaus \& Buetell dalam Ratna Darmayanti (2012), konfilik keluarga dengan pekerjaan terjadi ketika individu harus menghadapi tuntunan dari satu domain kepentingan (pekerjaan atau keluarga) yang menyebabkan kepentingan (peran) satu harus mengalahkan kepentingan yang lain. Misalnya, semakin banyak pria yang mengalami tuntunan dalam peran pekerjaan mereka bertentangan dengan tanggung jawab yang seharusnya mereka lakukan di rumah. Pekerjaan-pekerjaan yang menantang, sering malakukan perjalanan jauh dan jam kerja yang sama dapat dengan mudah menimbulkan konflik dengan tekanan-tekanan dan keinginan-keinginan untuk ikut serta dalam aktivitas keluarga.

Konflik keluarga - pekerjaan menimbulkan efek negative bagi pekerja maupun bagi keluarga. Bentuk efek negative konflik keluarga - pekerjaan dalam peran keluarga adalah ketidakpuasan hidup dan pernikahan ( Lingard dan Farnar, dalam Nur Saina, 2013). Sedangkan dalam peran pekerjaan, konflik keluarga - pekerjaan akan menimbulkan kelelahan kepuasan kerja akan mempengaruhi prilaku individu dalam organisasi seperti tingkat absensi, perputaran karyawan dan pada akhirnya akan menimbulkan keinginan untuk berpindah ( Judge\& Ilies, dalam Nur Saina, 2013).

Guitian dalam Alfiah (2013) mengutip pendapat beberapa hasil penelitian sebelumnya yang menjelaskan bahwa konflik pekerjaan keluarga berkorelasi dengan (1) Ketidak hadiran, (2) Penurunan produktivitas, (3) Ketidak puasan kerja, (4) Penurunan komitmen organisasi, (5) Kurangnya kepuasan hidup, (6) Kecemasan \& kelelahan, (7) Stress \& depresi pekerjaan, (8) Penyakit fisik, dan (9) Pengunaan alkohol \& ketegangan dalam pernikahan.

Sekaran dalam Alfiah (2013) menemukan bahwa pasangan suami istri yang sama-sama bekarir akan lebih banyak mengalami konflik peran. Menjadi suatu keluhan umum bahwa wanita sering kali merasakan kesukaran untuk dapat mengkombinasikan peran dalam pekerjaan dan keluarga. Herman dan Gyllstrom dalam Giovany Anggasta Buhali (2013) menemukan bahwa individu yang sudah menikah akanmengalami lebih banyak konflik pekerjaan keluarga dibandingkam individu yang belum menikah. Dalam kontek yang sama individu yang beperan sebagai orang tua akan mengalami konflik keluargapekerjaan lebih tinggi dibandingan individu yang tidak berperan sebagai orang tua. Frone, Russell \& Cooper, dalam Darmayanti Ratna (2012) mendefinisikan konflik keluarga-pekerjaan sebagai konflik peran yang terjadi pada karyawan, dimana di satu sisi ia harus melakukan pekerjaan di kantor dan di sisi lain harus memperhatikan keluarga secara utuh, sehingga sulit membedakan antara pekerjaan mengganggu keluarga dan keluarga mengganggu pekerjaan. Pekerjaan mengganggu keluarga, artinya sebagian besar waktu dan perhatian dicurahkan untuk melakukan pekerjaan sehingga kurang mempunyai 
waktu untuk keluarga. Sebaliknya keluarga mengganggu pekerjaan berarti sebagian besar waktu dan perhatiannya digunakan untuk menyelesaikan urusan keluarga sehingga mengganggu pekerjaan. Konflik pekerjaan-keluarga ini terjadi ketika kehidupan rumah seseorang berbenturan dengan tanggung jawabnya di tempat kerja, seperti masuk kerja tepat waktu, menyelesaikan tugas harian. Demikian juga tuntutan kehidupan rumah yang menghalangi seseorang untuk meluangkan waktu untuk pekerjaannya atau kegiatan yang berkenaan dengan kariernya.

Sependapat dengan Frone, Greenhaus dan Parasuraman dalam Darmayanti Ratna (2012) mengemukakan bahwa konflik keluarga-pekerjaan terjadi karena karyawan berusaha untuk menyeimbangkan antara permintaan dan tekanan yang timbul, baik dari keluarga maupun yang berasal dari pekerjaannya. Gutek et al, dalam Darmayanti Ratna (2012) menyebutkan bahwa konflik pekerjaan-keluarga (work family conflict) mempunyai dua komponen yaitu (1) Urusan keluarga mencampuri pekerjaan (Family interference with work) dan (2) Urusan pekerjaan mencapuri keluarga (Work interference with family).

Konflik pekerjaan-keluarga dapat timbul dikarenakan urusan pekerjaan mencampuri urusan keluarga seperti banyaknya waktu yang dicurahkan untuk menjalankan pekerjaan menghalangi seseorang untuk menjalankan kewajibannya di rumah, atau urusan keluarga mencampuri urusan pekerjaan (seperti merawat anak yang sakit akan menghalangi seseorang untuk datang ke kantor).

Beberapa peneliti menemukan bahwa wanita cenderung menghabiskan lebih banyak waktu dalam hal urusan keluarga sehingga wanita dilaporkan lebih banyak mengalami konflik pekerjaan-keluarga khususnya family interference with work (Berk et al, dalam Darmayanti Ratna, 2012). Sebaliknya pria cenderung untuk menghabiskan lebih banyak waktu untuk menangani urasan pekerjaan daripada wanita sehingga pria dilaporkan lebih banyak mengalami konflik pekerjaankeluarga khususnya work interference with family dari pada wanita. Soeharto,T. (2010) mengadakan penelitian yang membahas tentang konflik keluarga-pekerjaan dengan kepuasan kerja pada karyawan. Dengan hasil ini dapat menunjukan bahwa ada hubungan negatif konflik pekerjaan-keluarga dengan kepuasan kerja pada semua karakteristik.sikap dan perasaan yang negatif terhadap pekerjaan merupakan akbiat dari konflik pekerjaan-keluarga yang dialami, sebaliknya individu yang dapat menyeimbangkan peran dalam pekerjaan dan keluarga akan membuat individu merasa dan bersikap positif terhadap pekerjaan.

Penelitian yang dilakukan Alfiah (2013) atas pengaruh. Konflik terhadap kepuasan kerja melalui kepercayaan. Penelitian ini membuktikan bahwa kepercayaan memediasi hubungan antara konflik dengan kepuasan kerja. Sehingga konflik tidak berpengaruh secara langsung terhadap kepuasan kerja, akan tetapi melalui kepercayaan (kepercayaan organisasi, kepercayaan kepada atasan maupunkepercayaan rekan kerja). Penelitian yang dilakukan oleh Kussudyarsana (2008) menguji tentang pengaruh karier pada wanita terhadap konflik keluarga-pekerjaan pada Universitas Muhammdiyah Surakarta. Penelitian ini memperlihatkan tingkat intensitas konflik pekerjaan-keluarga yang rendah.Pekerjaan tidak membuat tekanan berarti dalam kehidupan berkeluarga.Hasil penelitian juga tidak mengkonfimasi adanya perbedaan tingkat intensitas konflik antara wanita karier yang menduduki jabatan struktural dengan non structural. 


\section{Metodologi Penelitian}

Populasi dalam penelitian ini adalah Perguruan Tinggi Swasta di Kota Prabumulih, STMIK YPP Prabumulih, STIE YPP Prabumulih dan STIE AL-Furqon Sampel dalam penelitian ini adalah dosen yang mengajar di institusi tersebut, minimal 2 tahun telah mengajar di institusi tersebut, dan pendidikan minimal S2. Berdasarkan pembatasan tersebut, maka sampel yang digunakan dalam penilian ini berjumlah 75 responden. Sampel dalam penelitian ini diambil dengan menggunakan teknik sampling insidental,sampel yang digunakan berdasarkan pada dosen yang kebetulan pada saat ditemui sesuai atau cocok syarat sampel. Metode analisis data yang digunakan dalam penelitian ini adalah analisis deskriptif kualitatif, yang meliputi analisis regresi sederhana, analisis koefisien korelasi, dan koefisien determinasi.

\section{Hasil dan Pembahasan}

Berikut disajikan hasil pengujian normalitas. Dari hasil diatas pada kolom kolmogorovsmirnov dapat diketahui bahwa nilai signifikan untuk konflik sebesar 0,66, untuk kepuasan sebesar 0,70. Karena signifikan untuk seluruh variabel lebih besar dari 0,05 maka dapat disimpulkan bahwa data pada konflik dan kepuasan berdistribusi normal.

Tabel 1. Tests of Normality

\begin{tabular}{|l|c|c|c|c|c|c|c|}
\hline \multirow{2}{*}{} & \multicolumn{3}{|c|}{ Kolmogorov- $^{2}$} & \multicolumn{3}{|c|}{ Smirnov } & \multicolumn{3}{c|}{ Shapiro-Wilk } \\
\cline { 2 - 9 } & & $\begin{array}{c}\text { Stati } \\
\text { stic }\end{array}$ & Df & Sig. & $\begin{array}{c}\text { Stati } \\
\text { stic }\end{array}$ & df & Sig. \\
\hline Konflik & & .099 & 75 & .066 & .986 & 75 & .560 \\
Kepuasan & & .098 & 75 & .070 & .963 & 75 & .029 \\
\hline
\end{tabular}

a. Lilliefors Significance Correction

Tabel 2 menunjukkan hasil koefisien korelasi. Dapat dilihat pada kolom kolmogorovsmirnov dapat diketahui bahwa nilai signifikan untuk konflik sebesar 0,66, untuk kepuasan sebesar 0,70. Karena signifikan untuk seluruh variabel lebih besar dari 0,05 maka dapat disimpulkan bahwa data pada konflik dan kepuasan berdistribusi normal.

Tabel 2. Hasil Analisis Korelasi Bivariate Pearson

\begin{tabular}{|c|c|c|c|}
\hline & & konflik & $\begin{array}{c}\text { Kepuasa } \\
\text { n }\end{array}$ \\
\hline \multirow[t]{3}{*}{ Konflik } & $\begin{array}{l}\text { Pearson } \\
\text { Correlation }\end{array}$ & 1 & $-.421^{* *}$ \\
\hline & Sig. (2-tailed) & & .000 \\
\hline & $\mathrm{N}$ & 75 & 75 \\
\hline \multirow[t]{3}{*}{ Kepuasan } & $\begin{array}{l}\text { Pearson } \\
\end{array}$ & $-.421^{* * *}$ & 1 \\
\hline & Sig. (2-tailed) & .000 & \\
\hline & $\mathrm{N}$ & 75 & 75 \\
\hline
\end{tabular}

Berdasarkan Tabel 3 diatas diperoleh persamaan regresi sebagai berikut :

$\mathrm{Y}=\mathrm{a}-\mathrm{bX}$

$\mathrm{Y}=6,083-0,910$ konflik 
Dari persamaan regresi sederhana diatas diketahu dapat diperoleh nilai a $=6,083$ dimana apabila tidak ada konflik atau $X=0$, maka kepuasan kerja adalah sebesar 6,083. Sedangkan $b=-0,910$ (negative) maka model regresi bernilai negative (tidak searah), artinya jika nilai variabel konflik keluarga-pekerjaan (X) semakin tinggi maka nilai kepuasan kerja (Y) rendah.

Tabel 3. Hasil Regresi

\begin{tabular}{|lc|r|r|r|r|r|}
\hline \multirow{2}{*}{ Model } & \multicolumn{2}{|c|}{$\begin{array}{c}\text { Unstandardized } \\
\text { Coefficients }\end{array}$} & \multicolumn{2}{c|}{$\begin{array}{c}\text { Standardized } \\
\text { Coefficients }\end{array}$} & \multirow{2}{*}{} \\
\cline { 3 - 5 } & \multicolumn{1}{|c|}{$\mathrm{B}$} & Std. Error & Beta & \multicolumn{1}{c|}{ T } & \multicolumn{1}{c|}{ Sig. } \\
\hline & (Constant) & 6.083 & .704 & & 8.642 & .000 \\
& Konflik & -.910 & .229 & -.421 & -3.970 & .000 \\
\hline
\end{tabular}

a. Dependent Variable: kepuasan

Dari hasil Tabel 4 dapat dilihat nilai pada baris regression pada kolom sig didapatkan nilai 0,000 berarti $P$ value sig adalah 0,00 artinya karena nilai $P$ value sig kurang dari 0,05 maka disimpulkan terdapat pengaruh signifikan antara konflik keluarga - pekerjaan (X) dengan kepuasan kerja (Y).

Tabel 4. Hasil ANOVA

\begin{tabular}{|c|c|c|c|c|c|}
\hline Model & $\begin{array}{l}\text { Sum of } \\
\text { Squares }\end{array}$ & Df & $\begin{array}{c}\text { Mean } \\
\text { Square }\end{array}$ & $\mathrm{F}$ & Sig. \\
\hline 1 Regression & 1.484 & 1 & 1.484 & 15.762 & $.000^{\mathrm{b}}$ \\
\hline Residual & 6.871 & 73 & .094 & & \\
\hline Total & 8.355 & 74 & & & \\
\hline
\end{tabular}

a. Dependent Variable: kepuasan

b. Predictors: (Constant), konflik

Dari hasil Tabel 5, maka dapat disimpulkan bahwa hubungan yang ditimbulkan antara konflik keluarga - pekerjaan terhadap kepuasan kerja adalah cukup dan positif dengan koefisien korelasi sebesar 0,421 yang berada pada interval koefisien $(0,40-0,599)$. Sehingga terdapat cukup hubungan antara konflik terhadap kepuasan kerja.

Tabel 5. Analisis Koefisien Korelasi ( r )

\begin{tabular}{|l|r|r|r|r|}
\hline & & & $\begin{array}{c}\text { Adjuste } \\
\mathrm{d} R \\
\text { Model }\end{array}$ & \multicolumn{1}{c|}{$\begin{array}{c}\text { Std. Error of the } \\
\text { Estimate }\end{array}$} \\
\hline 1 & $\mathrm{R}$ & $\mathrm{R}$ Square & \multicolumn{1}{c|}{ Square } \\
\hline
\end{tabular}

a. Predictors: (Constant), konflik

b. Dependent Variable: kepuasan

Dapat dilihat dari hasil Tabel 6, diperoleh koefisien determinasi $\left(\mathrm{R}^{2}\right)$ sebesar 0,178 yang mengandung pengertian bahwa pengaruh konflik keluarga-pekerjaan terhadap kepuasan kerja adalah sebesar 17,8, sedangkan sisanya dipengaruhi oleh faktor lain yang tidak diteliti. 
Tabel 6. Analisis Koefisien Determinasi $\left(\mathrm{R}^{2}\right)$

\begin{tabular}{|l|r|r|r|c|}
\hline Model & \multicolumn{1}{|c|}{$\mathrm{R}$} & R Square & \multicolumn{1}{c|}{$\begin{array}{c}\text { Adjusted } \mathrm{R} \\
\text { Square }\end{array}$} & $\begin{array}{c}\text { Std. Error of the } \\
\text { Estimate }\end{array}$ \\
\hline 1 & $.421^{\mathrm{a}}$ & .178 & .166 & .30680 \\
\hline
\end{tabular}

a. Predictors: (Constant), konflik

b. Dependent Variable: kepuasan

\section{Simpulan}

Adanya pengaruh yang signifikan antara konflik keluarga - pekerjaan terhadap kepuasan kerja pada seorang dosen yang dibuktikan dengan hasil tabel 4.23 yaitu nilai p value signifikan $=0,000$ atau value signifikan $<0,05$ yang artinya terdapat pengaruh antara konflik keluarga - pekerjaan (X) terhadap kepuasan kerja ( Y). Berdasarkan hasil perhitungan koefisien korelasi dapat dinyatakan bahwa adanya hubungan yang cukup kuat antara konflik keluarga - pekerjaan terhadap kepuasan kerja artinya konflik yang dirasakan oleh seorang dosen berpengaruh dalam kepuasan kerja dosen pada perguruan tinggi swasta di Kota Prabumulih. Faktor - faktor yang mempengaruhi konflik keluarga - pekerjaan terhadap kepuasan kerja yaitu (1) Jenis Pekerjaan karena pekerjaan sebagai dosen awalnya bukan merupakan cita-cita atau keinginan sebelumnya yang diminatin oleh dosen; (2) Lokasi kerja karena jarak lokasi tempat seorang dosen mengajar saat ini jauh dari tempat tinggalnya karena itulah kadang menjadi kendala atau konflik bagi dosen sehingga kepuasan kerja pun berkurang; (3) Prilaku pasangan karena kurangnya komunikasi antara keluarga saat bekerja membuat konflik keluarga-pekerjaan sehingga menimbulkan kurangnya kepuasan kerja dan (4) Gaji karena terkadang gaji atau tunjangan yang didapat dari institusi tidak sesuai dengan kinerja sebagai dosen sehingga membuat dosen merasa tidak puas.

\section{Daftar Pustaka}

Alfiah, J. (2013). Pengaruh konflik terhadap kepuasan kerja melalui kepercayaan. Jurnal Manajemen, Fakultas Ekonomi, Universitas Negeri Surabaya.

Buhali, G.A. (2013). Pengaruh work-family cobflict terhadap komitmen organisasi; kepuasan kerja sebagai variabel mediasi. Jurnal Manajemen, 13(1).

Dharmayanti R. (2012). Pengaruh konflik keluarga-pekerjaan, keterlibatan pekerjaan, dan tekanan pekerjaan terhadap kepuasan kerja karyawan wanita. Studi Manajemen \& Organisasi, 3(2).

Irham, F. (2012). Manajemen Kepemimpinan Teori dan Aplikasi. Bandung: Alfabeta.

Jati, A. (2011). Kesejahteraan subjektif dan kepuasan kerja pada staff pengajar (dosen) di lingkungan Fakultas Psikologi Universitas Diponegoro. Universitas Undip, 8(2).

Onsardi. (2002). Pengaruh tekanan pekerjaan, keterlibatan pekerjaan, konflik keluarga pekerjaan dan dukungan sosial terhadap kepuasan kerja karyawan pada perguruan tinggi swasta di Kota Bengkulu. Program Pascasarjana Fakultas Ekonomi. Universitas Diponegoro.

Saina, N. (2013). Konflik, stress kerja dan kepuasan kerja pengaruhnya terhadap kinerja pegawai pada Universitas Khairun Ternate. Jurnal EMBA, 1(3).

Soepatini dan Kussudyarsana. (2008). Pengaruh karier objektif pada wanita terhadap konflik keluarga pekerjaan kasus pada Universitas Surakarta. Jurnal Humaniora, 9(2). 
Sugiyono. (2007). Metode Penelitian Manajemen, Kuantitatif, Kualitatif dan R\&D. Bandung : Alfabeta

Sutrisno, E. (2009). Manajemen Sumber Daya Manusia. Jakarta: Kencana Prenada Media Group.

Wibowo. (2007). Manjemen Kinerja. Jakarta: Raja Grafindo Persada.

\section{Copyright Disclaimer}

Copyright for this article is retained by the author(s), with first publication rights granted to the journal. 